\title{
Fuzzy decision support model for the selection of contractor in construction works
}

\author{
Modelo difuso de apoyo para la selección de contratistas en obras de construcción
}

Cemil Akcay (Main and corresponding author)

Istanbul University-Cerrahpasa, Department of Civil Engineering

Istanbul (Turkey)

cakcay@istanbul.edu.tr

\section{Ekrem Manisalı}

Istanbul University, Department of Civil Engineering

Istanbul (Turkey)

ekmanisali@istanbul.edu.tr

Manuscript Code: 953

Date of Acceptance/Reception: 13.07.2018/01.08.2017

DOI: 10.7764/RDLC.17.2.258

\begin{abstract}
The major employer in Turkish construction sector is the public and the selection of contractor within the public sector is implemented in accordance with the regulations. Sound utilization of public resources in developing countries with certain development plans is very important; also the establishment of transparency and competition in public procurement increases saving and encourages the correct usage of tax revenues. Within this context, keeping the quality while increasing the level of competition and having successful public investments will be possible by selecting the most ideal contractor. The key for success in public investments on construction projects is to provide the minimum project cost with the ability to reach at the required quality level within the determined period; and therefore some criteria other than the amount of bid should be determined for construction tenders and the evaluation should be one within the scope of such criteria in order to select the contractor. A fuzzy logic methodology is used within the scope of this study, in which the criteria except the price are evaluated with the help of a model and the verbal terms are modeled.
\end{abstract}

Key words: Fuzzy logic, decision support system, public tender act, construction sector.

Resumen

El principal empleador en el sector de la construcción turco es el público y la selección del contratista dentro del sector público se lleva a cabo de conformidad con la normativa. La buena utilización de los recursos públicos en los países en desarrollo con ciertos planes de desarrollo es muy importante. También es el establecimiento de la transparencia y la competencia en la contratación pública lo que aumenta y conserva el uso correcto de los ingresos fiscales. En este contexto, será posible mantener la calidad mientras se aumenta el nivel de competencia y se obtienen inversiones públicas exitosas seleccionando al contratista más idóneo. La clave del éxito en los proyectos de inversión pública es proporcionar el costo mínimo del proyecto con la capacidad de alcanzar el nivel de calidad requerido dentro del período determinado; y por lo tanto, se deben determinar algunos criterios distintos del monto de la oferta para las licitaciones de construcción y la evaluación debe realizarse dentro del alcance de dichos criterios para seleccionar al contratista. Se utiliza una metodología de lógica difusa dentro del alcance de este estudio, en el que se excluyen los criterios.

Palabras clave: Lógica difusa, sistema de apoyo a la decisión, concurso público, sector de la construcción.

\section{Introduction}

It is a known fact that the extremely low offers are generally tend to be accepted after the evaluation, and that the tender committees do not take the responsibility to reject such bids. Within this scope, it is expected to reach a level of quality with the bidder contractors whose bids have been accepted after an efficient control. In the study, Istanbul University construction tenders were evaluated and as a result of this, it has been revealed that certain problems were experienced with the companies which have obtained the work due to extremely low bids. This case was accepted by Public Procurement Agency and paved the way to reject extremely low bids in terms of certain rates of threshold value.

Public purchases have reached to 7 trillion US Dollars at international scale and as its share within Gross Domestic Product increases day by day, it is assumed that its share will become more than $30 \%$ in the GDP of countries in the future. The major employer in Construction sector of Turkey is the public sector and public expenditures for construction, good and service purchases cover $12 \%$ of Gross Domestic Product (GDP) and this rate increases in Turkey as growth rate does (Turşucu, 2011). Within this scope, productive utilization of public resources becomes important.

Table 1 indicates the Public procurements that have been realized in the first six months of 2015 in Turkey. 


\begin{tabular}{lcccc}
\hline & \multicolumn{2}{c}{$\begin{array}{c}\text { Public procurement quantity } \\
\text { (pcs.) }\end{array}$} & \multicolumn{2}{c}{$\begin{array}{c}\text { Public procurement amount } \\
\text { (1000 TRY) }\end{array}$} \\
\hline Tender Type & 2015 & $\%$ & 2015 & $\%$ \\
\cline { 2 - 5 } Product Purchase & 40,321 & 56.15 & $13,419,215$ & 19.07 \\
Construction Work & 11,880 & 16.54 & $21,859,627$ & 31.07 \\
Service Purchase & 19,294 & 26.87 & $34,813,209$ & 49.48 \\
Consultancy Service Purchase & 310 & 0.44 & 261,830 & 0.38 \\
Total & 71,805 & 100.00 & $70,353,882$ & 100.00 \\
\hline
\end{tabular}

As the Public Procurement Law No. 2886 could not solve the problems faced in practice and due to the EU Directives Turkey has to comply because of its European Union (EU) candidacy position; Public Tender Law No. 4734 became valid in 2003 for works that require public expenditure and this law is still being applied by making the necessary amendments from time to time. This Law aims to realize the goals for public procurement as stated below (Gök, 2005; KIK, 2003).

- $\quad$ Transparency

- Competitiveness

- Equal treatment

- Reliability

- Public Scrutiny

- Meeting the requirements in a proper time and under proper conditions

- $\quad$ Effective utilization of resources

According to Public Procurement Law no. 4734, tender is defined as "the transactions completed by signing a contract with the real or legal person to be selected from among the bidders of good or service procurement following the approval of tender authority". Law defines the concept of building as "constructing buildings, highway, railway, motorway, airport, dock, port, shipyard, bridge, tunnel, metro, viaduct, sport facility, infrastructure, pipe transmission line, communication and energy transfer line, dam, energy plant, refinery, irrigation facility, soil reclamation, flood protection and pickling; and all types of installations, production, transportation, completion, major restoration, landscaping, drilling, enforcement and assembly works". According to the statistics for first 6 months of 2015; construction works projects constitute $31 \%$ of public expenditure which sum up to 24 billion USD (KIK, 2015a); and their achievement will be possible if they are completed with the expected quality and with minimum costs. The optimum point of three factors defined as Quality, Time and Cost triangle is the achievement point of construction projects. Selecting the contractor in public tenders becomes a very important issue in order to complete the construction projects successfully (Karaman \& Kale, 2007).

This study will reveal the criteria for selecting the contractors with a different perception (Akcay, Sayin \& Karakas, 2010; Akcay, Sayin, Karakaş \& Manisalı, 2011). These criteria will be modeled by Fuzzy Logic System as it is very similar to human thought system and as the verbal statements can be expressed mathematically (Şen, 2001; Mete, 2007; Ross, 2005; Şen, 2003; Taçgın, 2002; Zimmerman, 2001). Criteria will be determined in accordance with the laws and regulations in Turkey, experiences in practice and EU Public Tender Directives.

Description of the problem

Evaluating the construction work applications in Turkey, it is known that the lowest bid that meets the criteria is evaluated as the appropriate price. It is a known fact that the extremely low offers are generally tend to be accepted after the evaluation, and that the tender committees do not take the responsibility to reject such bids. Within this context, it is expected to reach a level of quality with the bidder contractors whose bids have been accepted after an efficient control.

State of the art

\section{Fuzzy cluster and fuzzy logic}

Concept of fuzzy logic was first mentioned by Lotfi A. Zadeh from University of California Berkeley. Fuzzy logic is defined as a mathematical model developed for the expression of uncertainties and to process such uncertainties into usable data (Bellman \& Zadeh, 1970). 
As a classic cluster consists of numbers One and zero, there are thousands of numbers between one and zero in fuzzy logic. The differences in a classical cluster and a fuzzy cluster are;

- In classic clusters, the element of $X$ is either an element of a cluster or not. Level of membership is either one or zero. In fuzzy clusters, there are values between zero and one for the level of membership.

- The intersection of elements and non-elements of a cluster is not considered as a blank cluster and its unity is not considered as universal cluster in fuzzy clusters.

- If the element $X$ does not belong to cluster $Y$, then it is not its element; but in fuzzy clusters, element $X$ can still be the element of that cluster even though it does not belong to cluster $Y$.

In classical logic, there are two evaluations as true and false; but in fuzzy logic, there are levels of true and false (Şen, 2001). The advantages of fuzzy logic model can be stated as its applicability without any complex mathematical models, its low cost and its ability to solve problems in a short time (Baykal \& Beyan, 2004).

Concept of fuzzy logic can be stated in four steps:

- Fuzzy Cluster: Fuzzy clusters are used to indicate the statements with words.

- Membership functions: It is used to determine the belonging levels of variables which are members of fuzzy clusters.

- Fuzzy operators: The logical relationships between the fuzzy statements are mentioned by fuzzy operators. For instance; "if", and", "or", "in that case".

- Fuzzy inference: It is obtaining new information from the existing ones by some rules, in other words, inference.

\section{Determination of criteria}

Various construction work tenders realized by Istanbul University, Department of Construction and Technical Affairs are evaluated in accordance with the items below (Akçay, 2008; Bilgen, 2001):

- Quality of work experience document

- Rate of updated amount of work experience document to the offer price

- Rate of unused cash credit amount to the offer price

- Rate of guarantee letter credit amount to the offer price

- Rate of extremely low offer limit to estimate cost

- The company that won the bid and the companies with extremely low bids;

- Rate of bids to estimate cost

- In companies that made extremely low bids

- Rate of bid to the limit value of extremely low bid

- In tenders that ask balance sheet and revenue table

- Current Ratio

- Total Own Resources

- Debt ratio

- Rate of 3-years average current value to the bid value

- Company evaluations of building control officers

As a result of evaluating the construction work tenders within the scope of this study, below facts were reached.

- If the companies that obtain work with extremely low bids are economically strong, they conduct quality work.

- Economically strong and experienced companies can stand behind their extremely low bids and they get works in the same rate.

- It has been concluded that those companies that participate in tender with work control or diploma instead of work experience document do not have the adequate experience.

- Companies which are very close to the extremely low bid limit can remain out of the tender.

- As the bids get more distant than the extremely low bid limit; their defense and acceptance by tender committees decreases.

- As the number of bidders increase, rate of giving extremely low bids increase as well.

Within the scope of these proofs, it has been concluded that non-price aspects, the financial capacity of bidders and the experience of company should be considered while evaluating the prices. 


\section{Evaluation according to EU criteria}

When the EU Directive 2004/18/EC (this will be replaced by 2014/24/EU Directive on April 18, 2016) (Directive 2004/18/EC, 2004) is reviewed in terms of determining the most economically advantageous bid; it is seen that the criteria below can be used (Bilgin, 2007):

- Price

- Quality

- Cost of operation and maintenance

- Term

- Technical support after construction

- Aesthetics

- Functional characteristics

- Environmental characteristics

Eight criteria stated above are evaluated according to non-price aspects and bid price weighting coefficient. Weight rates between non-price aspects and price change between 20/80 and 40/60 in innovative projects; between 15/85 and $35 / 65$ in complex projects and between $10 / 90$ and 25/75 in simple projects. In EU member countries; discounting from the price model and weighted evaluation model are known as the most frequently used ones (KIK, 2005).

\section{Criteria used for the selection of economically most advantageous bid}

Criteria used for the determination of economically most advantageous bid by considering the field study and EU criteria are shown in Figure 1 (Gencer, 2003; Akçay, 2003; Akçay \& Manisalı, 2007).

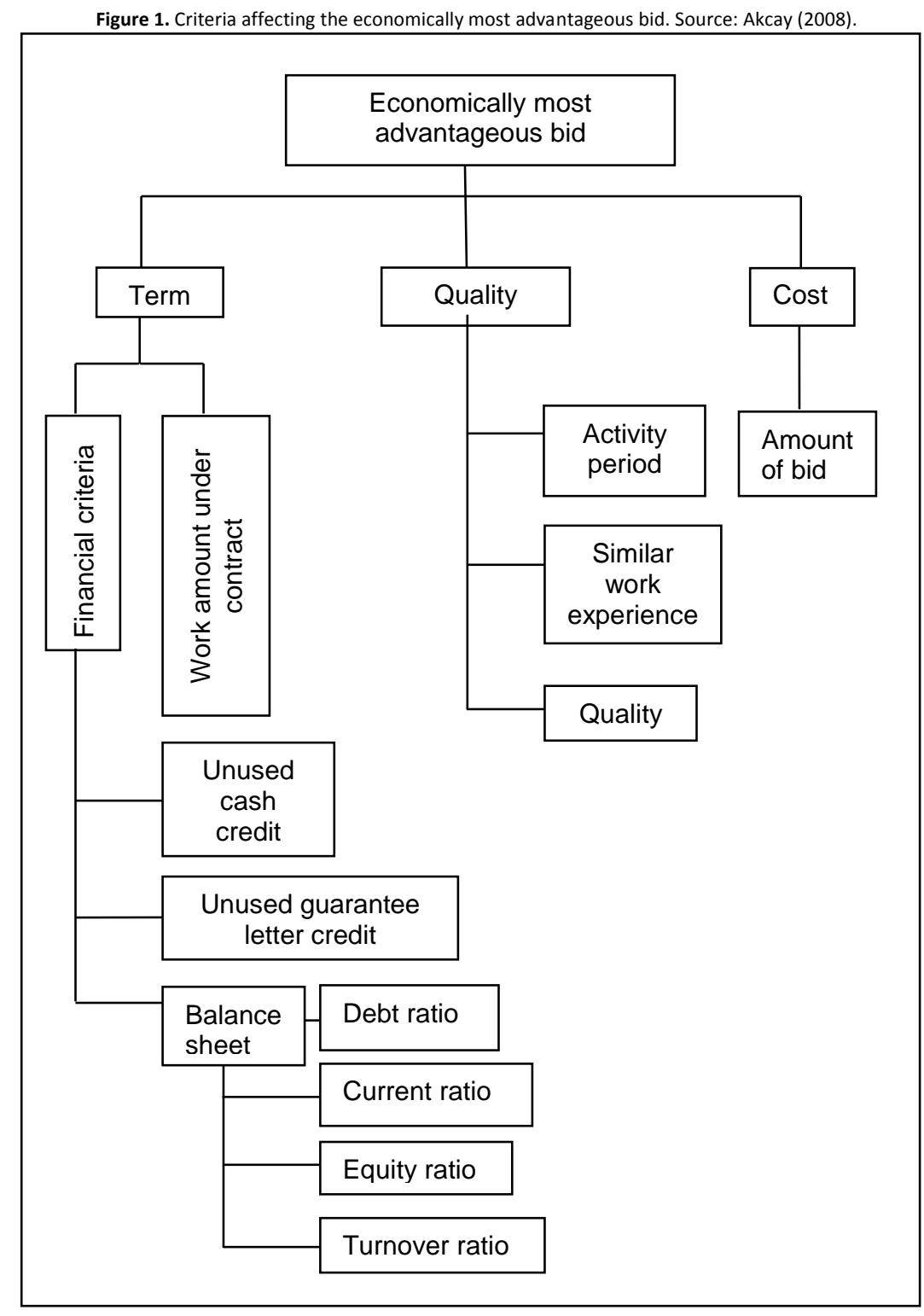


The criteria mentioned in chapter four will be used for the model to be generated within this study. With this model, companies will be classified by quality and duration criteria, independent from bid amount and those under a certain threshold will not be evaluated.

\section{First criteria: Free deposit}

Sum of unused cash credit and unused guarantee credit constitute the free deposit. According to this; fuzzy cluster in which Free deposit / Bid amount is evaluated as low, normal and high according to values between 0 and 1 are shown in Figure 2.

Figure 2. Free deposit/ Amount of bid criteria fuzzy cluster. Source: Akcay (2008).

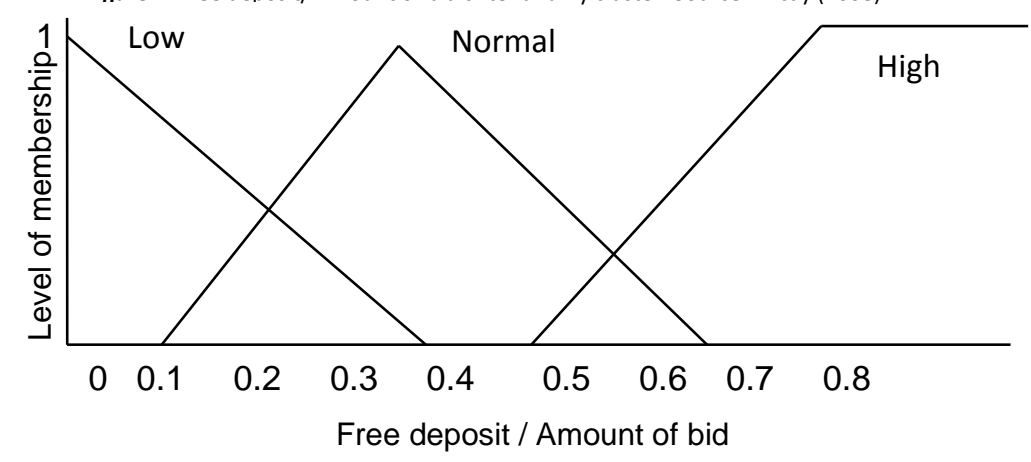

\section{Second criteria: Current ratio from balance sheet criteria}

Current ratio is calculated as the rate of current assets to short-term debts and it indicates whether a company has the ability to pay debt in short term (one year) and the necessary liquidity in order to provide the cash flow. The fuzzy cluster for the values between 0.5 and 3.0 are indicated in Figure 3.

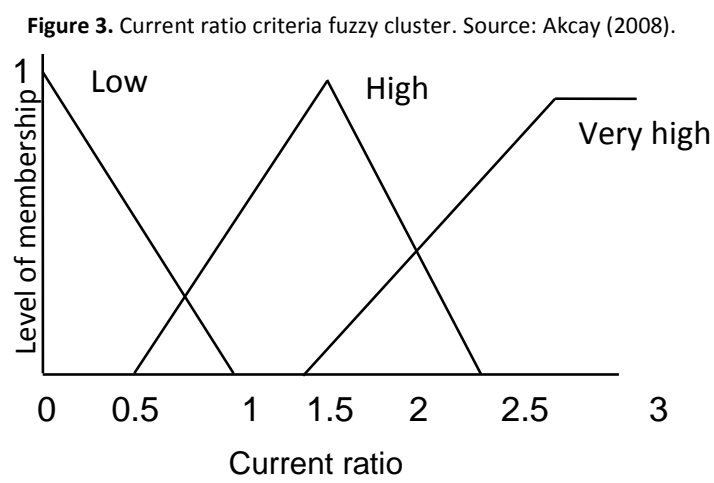

\section{Quality: Evaluation of bidders according to project performance}

If there are any works for which the bidders have participated in tender with the administrative unit; the fuzzy cluster evaluated in three categories as negative, neutral and positive between 0 and 10 in terms of quality, duration etc. are indicated in Figure 4.

Figure 4. Quality criteria fuzzy cluster. Source: Akcay (2008).

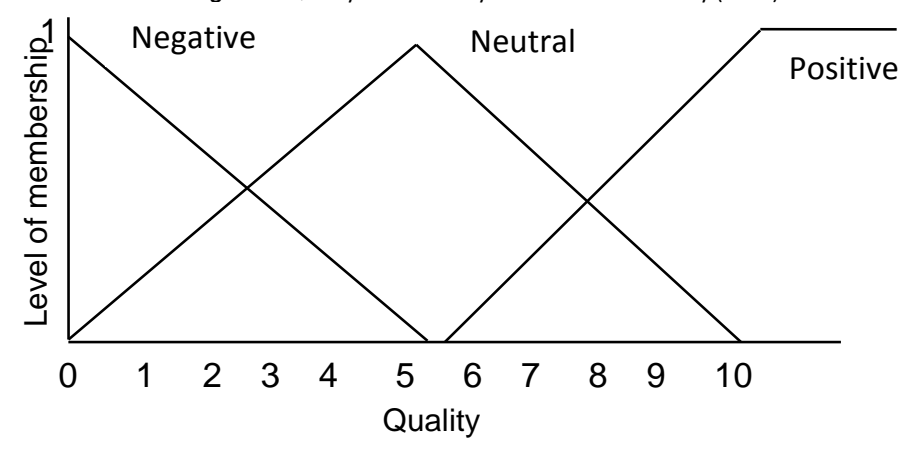




\section{Similar work experience}

It is the experience of the Company for the last fifteen years in the works which are in parallel with the work items planned to be conducted. Similar work is determined by rationing the current value of a completed work related with one contract in terms of Turkish Lira to the bid amount. Fuzzy cluster of similar work is indicated in Figure 5.

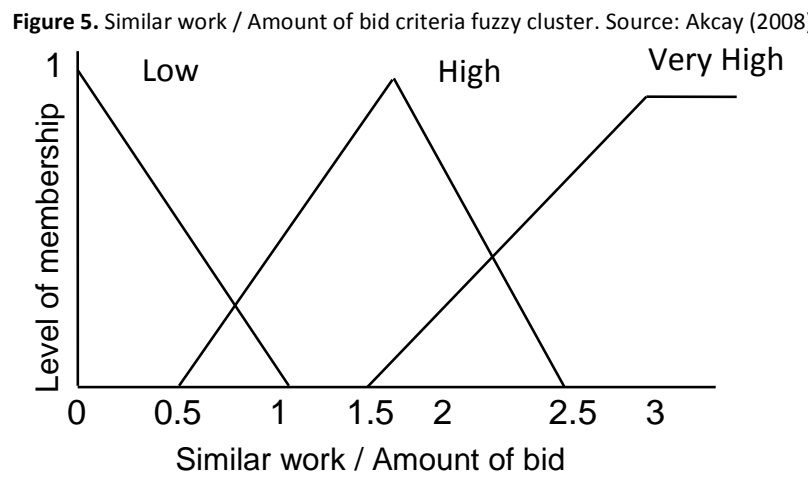

\section{Reparing the model in Matlab software}

The model was generated with Matlab computer program (Uzunoğlu \& Onar, 2003). Mamdani method is preferred for fuzzy inference method; whereas Centroid Method is preferred for clarification process. Table of rules is prepared under the light of evaluations of expert technical personnel. Model is displayed below (Figure 6). Generation of Table of Rules is indicated in Figure 7.

Figure 6. Model generated in Matlab software.

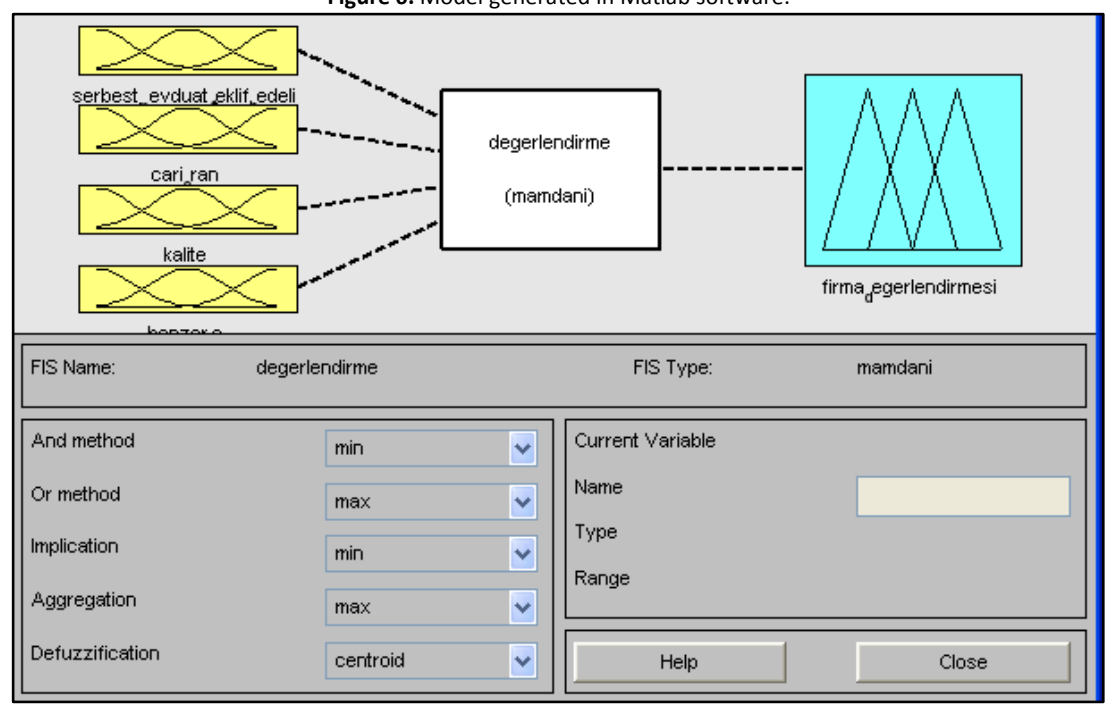

Figure 7. A screen shot from table of rules.

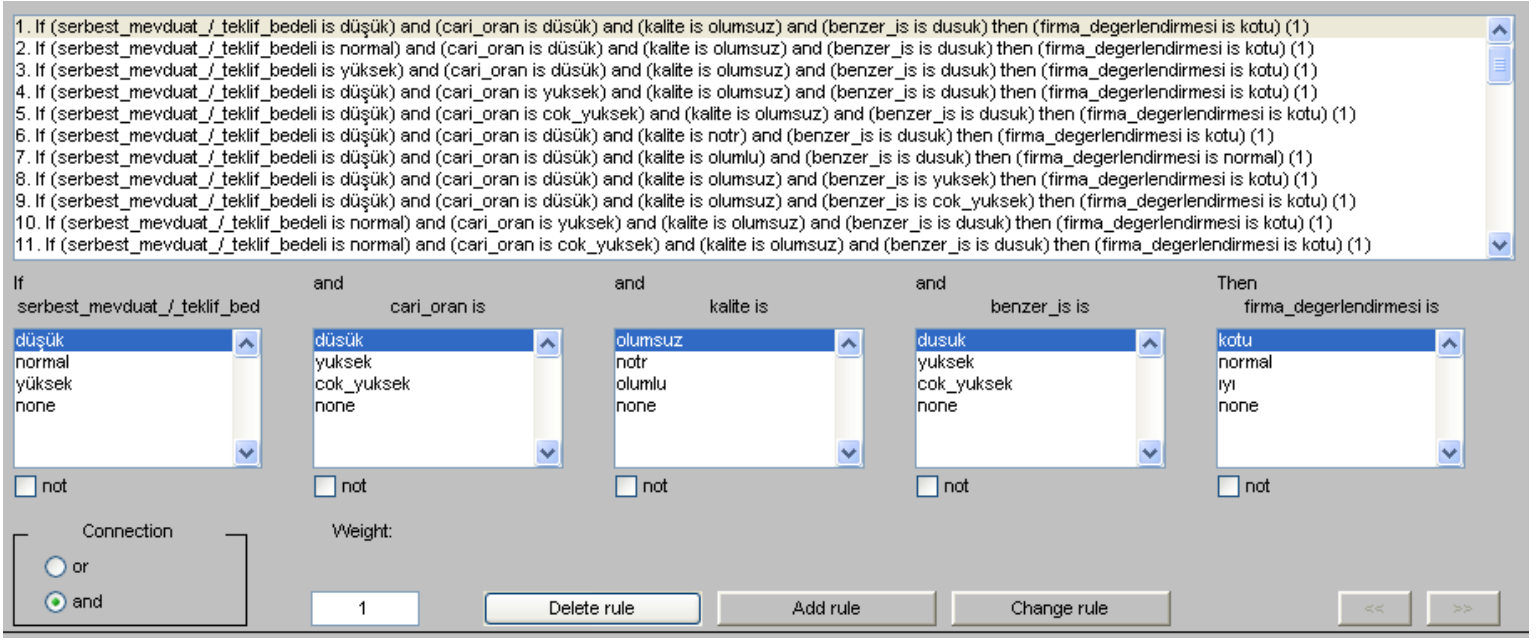


As a result of operation of the model; companies will be classified under three categories as low profile, moderate profile and high profile in terms of quality as can be seen in Figure 8.

Figure 8. Output generated as a result of the model.

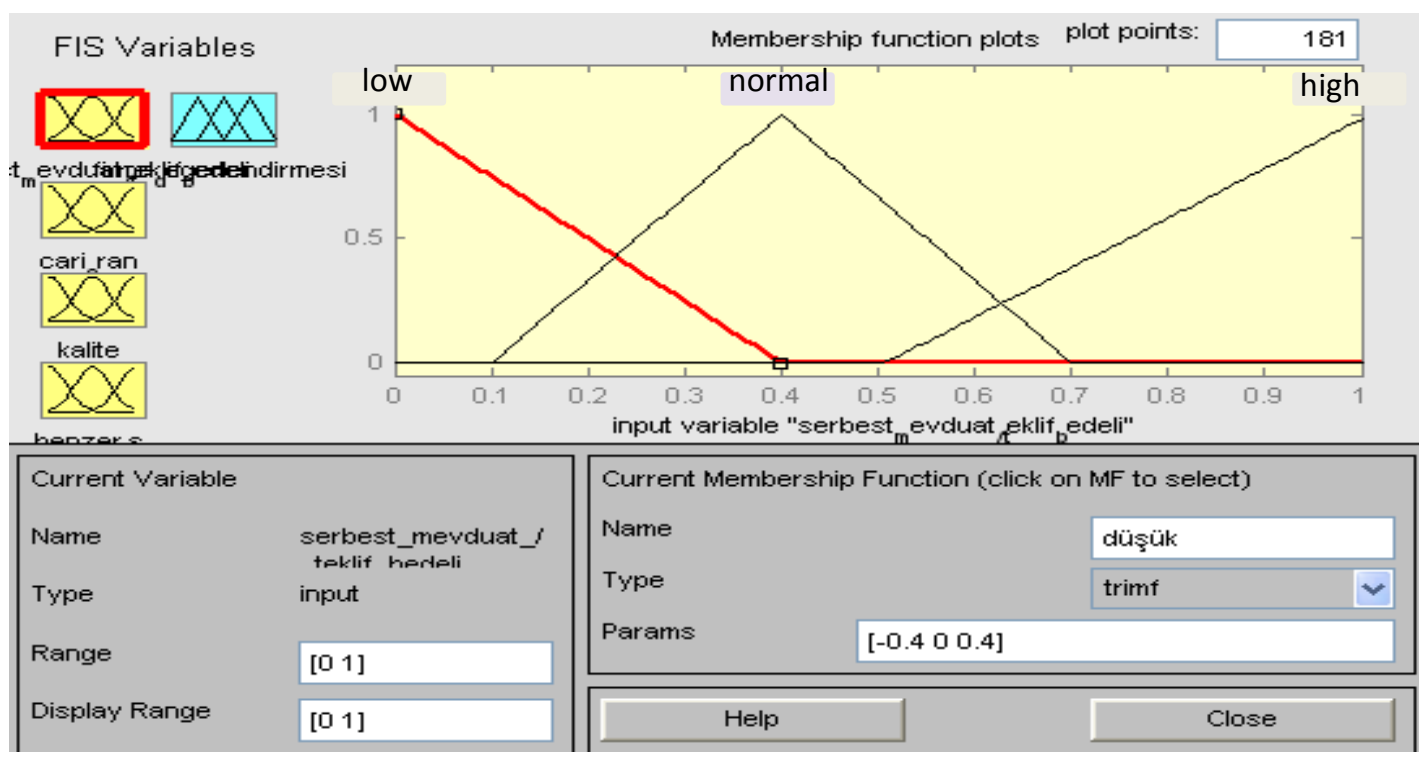

\section{Sample Application}

A construction work tender in which 5 companies have participated will be evaluated in terms of the model above. As a result of this evaluation, it is accepted that high profile companies will be assumed to be sufficient for tender. The data of companies and their evaluation according to criteria is indicated in Tables 2 and 3.

\begin{tabular}{cccccc}
\multicolumn{7}{c}{ Table 2. Data of the companies participating in tender. Source: Akcay (2008). } \\
\hline Bidders & Free deposit & $\begin{array}{c}\text { Current } \\
\text { ratio }\end{array}$ & Quality & $\begin{array}{c}\text { Similar work } \\
\text { (TRY) }\end{array}$ & $\begin{array}{c}\text { Amount of } \\
\text { bid (TRY) }\end{array}$ \\
\hline Company A & 475,000 & 0.75 & 8 & 475,000 & 475,000 \\
Company B & 400,000 & 1.50 & 10 & 900,000 & 450,000 \\
Company C & 375,000 & 1.00 & 0 & 425,000 & 425,000 \\
Company D & 450.000 & 2 & 3 & $1.200,000$ & 400,000 \\
Company E & 500.000 & 2 & 5 & 410,000 & 410,000 \\
\hline
\end{tabular}

\begin{tabular}{lccccc}
\multicolumn{6}{c}{ Table 3. Evaluation of Companies according to the criteria. Source: Akcay (2008). } \\
\hline & $\begin{array}{c}\text { Free deposit / } \\
\text { Bidders }\end{array}$ & $\begin{array}{c}\text { Current } \\
\text { Amount of bid }\end{array}$ & $\begin{array}{c}\text { Similar work / } \\
\text { Qutio }\end{array}$ & $\begin{array}{c}\text { Amount of bid } \\
\text { Quality }\end{array}$ & $\begin{array}{c}\text { Amount of bid } \\
\text { (TRY) }\end{array}$ \\
\hline Company A & 1.00 & 0.8 & 8 & 1 & 475,000 \\
Company B & 0.89 & 1.5 & 10 & 2 & 450,000 \\
Company C & 0.88 & 0.6 & 0 & 1 & 425,000 \\
Company D & 1.13 & 2.4 & 3 & 3 & 400,000 \\
Company E & 1.22 & 2.0 & 5 & 1 & 410,000 \\
\hline
\end{tabular}

The sorting of companies according to the scores they have received as a result of evaluation in the model can be seen in Table 4. The model evaluation result of Company B is indicated in Figure 9. As a result of the analyses, after the evaluation of scores of companies, $\mathrm{A}$ and $\mathrm{B}$ are considered as high profile companies. 


\begin{tabular}{lcc}
\multicolumn{3}{c}{ Table 4. Model evaluation results. Source: Akcay (2008). } \\
\hline Bidders & $\begin{array}{c}\text { Score } \\
\text { received }\end{array}$ & $\begin{array}{c}\text { Amount of bid } \\
\text { (TRY) }\end{array}$ \\
\hline Company A & 0.83 & 475,000 \\
Company B & 0.85 & 450,000 \\
Company C & 0.50 & 425,000 \\
Company D & 0.56 & 400,000 \\
Company E & 0.60 & 410,000 \\
\hline
\end{tabular}

In this study, Istanbul University construction tenders were evaluated and as a result of this, it has been revealed that certain problems were experienced with the companies which have obtained the work due to extremely low bids. This case was accepted by Public Procurement Agency and paved the way to reject extremely low bids in terms of certain rates of threshold value. This study has revealed a decision model by Fuzzy Logic which will feature other aspects that will affect quality and duration while deciding for the economically most advantageous bid for the tenders in construction works. The criteria stated in the model were acquired by evaluating the experiences from construction work tenders within the framework of related EU directives and the model was better understood with an example. It is assumed that, as electronic tools are being used for public procurements, the model generated within the scope of this study may be used in practice.

References

Akçay, C. (2008). Avrupa Uygunluk Kriterlerine Göre Bir Kamu Ihale Karar Destek Modeli, PhD thesis, Istanbul University, Science Institute, İstanbul, Türkiye.

Akçay, C., \& Manisalı, E. (2007). 4734 Sayılı Kamu Ihale Kanunu ve 4735 Sayılı Kamu Ihale Sözleşmeleri Kanunlarının AB Uygulamaları Çerçevesinde Uygulamada Karşılaşılan Sorunlar Açısından İncelenmesi. 4. İnşaat Yönetimi Kongresi, İstanbul, Türkiye.

Akçay, C. (2003). İnşaat Mühendisliğinde Fuzzy Logic Uygulama Örnekleri, MSc. thesis, Istanbul University, Science Institute, İstanbul, Türkiye.

Akçay, C., Sayın, B., \& Karakaş, A.S. (2010). Yapım İşleri Yüklenici Seçimine Yönelik Bir Bulanık Karar Destek Modeli. BMYS 2010: Bilimde Modern Yöntemler Sempozyumu, Diyarbakır, Türkiye.

Akçay, C., Sayın, B., Karakaş, A.S., \& Manisalı E. (2011). Bir Kamu ihale Karar Destek Modelinde Lineer ve Nonlineer Bulanık Küme Kullanımının Karşılaştırılması. 6. İnşaat Yönetimi Kongresi, Bursa, Türkiye.

Baykal, N., \& Beyan, T. (2004). Bulanık Mantık Illke ve Temelleri, Bıçaklar publishing, Ankara.

Bellman, R.E., \& Zadeh, L.A. (1970). Decision Making in a Fuzzy Environment Management, Management Science 17/4, 141-164.

Bilgen, Y., (2001). Türkiye'deki İhale Mevzuatı ve Avrupa Birliği İhale Mevzuatına Uyarlanması, Doktora Tezi, İstanbul Üniversitesi Fen Bilimleri Enstitüsü, ìstanbul. 
Bilgin, A. (2007). Türk ỉhale Mevzuatı ile 2004/18/EC Sayılı Direktif Arasındaki Temel Farklar, 4. İnşaat Yönetimi Kongresi, İstanbul.

Directive 2004/18/EC of the European Parliament and of the Council on the Coordination of Procedures for the Award of Public Works Contracts Public Supply Contracts and Public Service Contracts (2004/18/EC), and 30/04/2004, Official Journal of the European Union.

Gencer, H. (2003). En Ekonomik Teklifin Analitik Hiyerarşi Metodu İle Seçimi, İnşaat Mühendisleri Odası, İstanbul Bülteni, 4(64), 9-13.

Gök, Y. (2005). Tender Law with Descriptions, İlksan publishing, Ankara, Turkey.

Karaman, E., \& Kale, S. (2007). Bulanık hedef programlama yöntemi ile süre-kalite-maliyet eniyilemesi. 4. İnşaat Yönetimi Kongresi, Istanbul, Turkey. Mete, M. (2007). Bakım Yönetiminde Bulanık Çok Amaçlı Karar Verme Modeli, PhD thesis, Istanbul University, Science Institute, İstanbul, Türkiye.

Public Procurement Authority (KiK), (2003). Public Tender Law no., 4734, www.kik.gov.tr, Ankara.

Public Procurement Authority (KIK), (2005). Kamu Alımlarında AB ve İngiltere'deki Düzenleme ve Uygulamalar, Ankara.

Ross, T.J. (2005). Fuzzy Logic with Engineering Applications. John Wiley-Sons, p. 120, USA.

Şen, Z. (2001). Mühendislikte Bulanık Modelleme İlkeleri, Bilge Kültür Sanat, İstanbul.

Şen, Z. (2003). Modern Mantık, Bilge Kültür Sanat, İstanbul.

Taçgın, E. (2002). Fuzzy Logic Seminer Notları, Marmara Üniversitesi, İstanbul.

Turşucu, M. (2011). Public Procurement in terms of Public Expenditure Law and Practices in Turkey, Graduate thesis, p. 43, Isparta, Turkey.

Uzunoğlu, M., \& Onar, Ö.Ç. (2003). Her Yönü ile Matlab, Türkmen Kitabevi, İstanbul.

Zimmerman, H.J. (2001). Fuzzy Set Theory and Its Applications, Kluwer Academic Publishers 